\title{
ASPEK KEKERASAN SEBAGAI REFLEKSI DAN FORMATIF KONDISI SOSIAL POLITIK DI EKS-TIMOR TIMUR DALAM JAZZ PARFUM E INSIDEN KARYA SENO GUMIRA AJIDARMA
}

\author{
Nurhadi \\ FBS Universitas Negeri Yogyakarta \\ email: nurhadi2@yahoo.co.id
}

\begin{abstract}
This study aims to describe (1) aspects of violence in short stories in Jazz, Parfum, dan Insiden, (2) socio-political conditions as backgrounds to the violence, (3) the possibility for the fiction to reform society. The data source was Jazz, Parfum, dan Insiden by Seno Gumira Ajidarma. The data were analyzed by the content analysis employing the descriptive qualitative technique. The data trustworthiness was assessed through the semantic validity. The findings show that (1) aspects of violence include murder, torture, kidnap, rape, and other types of violence, (2) socio-political conditions as backgrounds to the violence are human right violations including the Dili incident at the Santa Cruz cemetery on 12 November 1991 and the conditions of the occupied East Timor in general, and (3) the fiction has a role in forming readers' awareness of violent acts by government apparatus in the occupation of East Timor by the New Order government that tended to be militaristic and authoritarian. The fiction indirectly gave contribution to the downfall of the New Order government and the independence of Timor Leste.
\end{abstract}

Keywords: violence, East Timor, literature's reflective role, literature's formative role

\section{PENDAHULUAN}

Timor Leste adalah negara baru yang berdiri secara resmi berdasarkan jajak pendapat tahun 1999. Dulunya, ketika masih tergabung dengan Republik Indonesia bernama Timor Timur, propinsi ke-27. Pemisahan diri Timor Timur memang diwarnai dengan suatu tindak kekerasan berupa pembakaran yang dilakukan oleh milisi yang kecewa dengan hasil referendum. Ada yang menengarai tindakan tersebut didukung oleh pihak militer Indonesia, meskipun hal itu dibantah oleh pihak keamanan Indonesia. Hubungan Indonesia sendiri dengan Timor Leste belakangan membaik meski ada beberapa kasus.

Pada 20 Januari 2006, Presiden Eks-Timor Timur, Xanana Gusmao menyampaikan laporan Komisi Penerimaan Kebenaran dan Rekonsiliasi
Timor Leste (CAVR) kepada Sekjen PBB. Dalam laporan itu disebutkan telah terjadi pembantaian terhadap 102.800 warga Timor Timur dalam kurun waktu 24 tahun, yakni ketika Timtim masih tergabung dengan Indonesia (1974-1999). Sekitar 85 persen dari pelanggaran HAM, menurut laporan CAVR, dilakukan oleh pasukan keamanan Indonesia (Kompas, 28 Januari 2006).

Dalam dokumen itu dikatakan bahwa militer Indonesia berusaha membasmi warga Timtim dengan meracuni makanan dan air, menggunakan napalm dan bahan kimia lainnya. Dalam rekomendasi CAVR juga disebutkan tentang perlunya memperbarui kontrak hakim-hakim internasional untuk Special Panels for Serious Crimes sehingga bisa mengadili semua pelaku kejahatan dari tahun 1974 hingga 1999. Menteri 
pertahanan Indonesia, Juwono Sudarsono, membantah kalau Indonesia menggunakan bom napalm di Timor Timur sejak 1974 karena hal itu bertentangan dengan kebijakan pemerintah. Menurut Juwono, yang dipersoalkan adalah penggunaan pesawat jenis Bronco buatan Amerika Serikat; kemudian muncullah isu Indonesia menggunakan napalm. Padahal waktu itu Indonesia tidak punya kemampuan mengimpor napalm (Kompas, 20 Januari 2006).

Pemerintah Indonesia sendiri dengan Timor Leste telah membentuk Komisi Kebenaran dan Persahabatan (KKP) guna menyelesaikan masalah pelanggaran HAM di masa lalu. KKP sendiri dideklarasikan pada 9 Maret 2005 oleh Presiden Susilo dan Presiden Xanana sebagai mekanisme yang dipilih kedua negara dalam menyelesaikan beban masa lalu yang terkait dengan pelanggaran HAM di Timtim pascajajak pendapat tahun 1999.

Dengan disampaikannya laporan CAVR oleh Xanana kepada Sekjen PBB, tidak tertutup kemungkinan pelanggaran HAM yang telah berlangsung dan telah diadili di pengadilan Indonesia, dapat ditinjau kembali, bisa jadi oleh PBB. Pelanggaran-pelanggaran pada masa lalu dapat ditinjau kembali. Hal ini akan mengingatkan tidak hanya pada sejumlah tindak kekerasan pascajajak pendapat, tetapi juga pada Peristiwa Insiden Dili, 12 November 1991 dan peristiwaperistiwa kekerasan lainnya.

Tindak kekerasan tersebut dapat dilacak dalam sejumlah pemberitaan media, meskipun untuk melakukan hal itu bukanlah pekerjaan mudah. Pada masa Orde Baru pers mengalami pengekangan untuk memberitakan halhal semacam itu. Tidak mudah bagi wartawan untuk dapat meliput peristiwa di Timor Timur. Meski demikian, dalam kesusastraan Indonesia, peristiwa-peristiwa kekerasan di Timor Timur muncul dalam karya-karya Seno Gumira Ajidarma, khususnya dalam antologi cerpennya yang berjudul Saksi Mata (1994) dan novelnya yang berjudul Jazz, Parfum dan Insiden (1996).

Karya sastra sebagaimana diyakini oleh Gramsci tidak hanya bersifat reflektif terhadap kehidupan masyarakat tetapi juga bersifat formatif terhadap masyarakat. Tokoh-tokoh new historisicism bahkan memandang karya sastra sejajar dengan buku-buku sejarah yang sama-sama membentuk wacana diskursif atas suatu peristiwa.

Dalam konteks pemikiran semacam itulah, artikel hasil penelitian ini mencoba membahas peran kedua karya sastra Indonesia yang memiliki keterkaitan dengan tindak kekerasan di EksTimor Timur itu, baik dari segi reflektifnya maupun segi formatifnya. Khusus dalam artikel ini hanya difokuskan pada novel Jazz Perfum E Insiden. Bagaimanakah tindak kekerasan berupa pelanggaran HAM tersebut direfleksikan dalam karya sastra Indonesia, dan bagaimana karya-karya tersebut pada gilirannya membentuk suatu wacana diskursif atas pelanggaran HAM pemerintah Indonesia di Eks-Timor Timur.

Dari sekian teori sastra yang berkembang selama ini, secara garis besar terbagi dalam dua kelompok. Yang pertama, teori-teori sastra yang lebih berorientasi pada struktur karya sastra seperti Formalisme, Strukturalisme, dan New Criticism; sementara yang kedua, yaitu teori sastra yang mengaitkan karya sastra dengan masyarakatnya atau yang sering dikategorikan dalam sosiologi sastra, baik Marxisme, Hegemoni Gramsci, Post-kolonial, New Historicism, maupun Cultural Studies. Selain itu, juga ada teori sastra yang berada di antaranya, sebut saja misalnya, Strukturalisme-Semiotik.

Wellek dan Warren (1990:77-134; Damono, 1979:3-6) membuat kategori 
pendekatan kritik sastra atas pendekatan intrinsik dan ekstrinsik. Sosiologi sastra dikategorikan dalam pendekatan ekstrinsik. Secara singkat, mereka membuat klasifikasi sosiologi sastra sebagai berikut. Pertama, sosiologi pengarang yang mempermasalahkan status sosial pengarang sebagai penghasil sastra. Kedua, sosiologi karya sastra yang mempermasalahkan karya sastra itu sendiri; yang menjadi pokok penelaahan adalah hal-hal yang tersirat dalam karya sastra dan apa yang menjadi tujuannya. Yang ketiga, sosiologi sastra yang mempermasalahkan pembaca dan pengaruh sosial karya sastra. Sebagaimana dikatakan oleh Damono (1979:3), Wellek dan Warren menganggap sosiologi sastra sebagai pendekatan ekstrinsik ini cenderung dalam pengertiannya yang negatif.

Di pihak lain, dengan klasifikasi yang tidak jauh berbeda dengan Wellek dan Warren, Ian Watt memandang sosiologi sastra dalam pengertian yang lebih positif. Dalam esainya, "Literature and Society", Ian Watt membicarakan hubungan timbal balik antara sastrawan, sastra, dan masyarakat (Damono, 1979:3-6; Faruk, 1994:4-5). Secara keseluruhan, hubungan timbal-balik tersebut adalah sebagai berikut.

Pertama, konteks sosial pengarang. Hal ini berhubungan dengan posisi sosial sastrawan dalam masyarakat dan kaitannya dengan masyarakat pembaca. Dalam pokok ini termasuk juga faktorfaktor sosial yang bisa mempengaruhi isi karya sastranya. Kedua, sastra sebagai cermin masyarakat; sampai sejauh mana sastra dapat dianggap sebagai cerminan keadaan masyarakat. Pengertian "cermin" di sini sangat kabur, dan oleh karenanya banyak disalahtafsirkan dan disalahgunakan (Damono, 1979:3-6; Faruk, 1994:4-5).

Menurut Eagleton (2002:61-62), karya sastra bisa dikatakan tidak berdiri dengan objeknya dalam bentuk refleksi, simetris, dan hubungan satu-satu. Objek sastra dirusak bentuknya (deformed), dibiaskan (refracted), dan dibubarkan (dissolved)-setidaknya menghasilkan kembali sebuah cermin yang kemudian memproduksi objeknya, barangkali dengan cara tampilan dramatik yang memproduksi ulang teks dramatik, atau mempertaruhkan contoh yang lebih menantang. Efek sastra pada hakikatnya lebih untuk merusak bentuk (deform) daripada meniru. Jika imaji keseluruhan dapat disamakan dengan realitas (seperti dalam sebuah cermin), imaji menjadi identik dengan realitas dan berhenti menjadi citra. Karakteristik gaya sastra yang menganggap semakin seseorang menjauhkan dirinya dari objek, semakin dia benar-benar menirunya. Hal tersebut menurut Macherey merupakan suatu model dari semua aktivitas artistik, sastra hakikatnya adalah parodik.

Ketiga, fungsi sosial sastra. Di sini kritikus terlibat dalam pertanyaan-pertanyaan seperti "Sampai seberapa jauh nilai sastra berkaitan dengan nilai sosial?", dan "Sampai seberapa jauh nilai sastra dipengaruhi nilai sosial?" Dalam hubungan ini, ada tiga hal yang harus diperhatikan: (a) sudut pandang ekstrim kaum romantik, misalnya, yang menganggap bahwa sastra sama derajatnya dengan karya pendeta atau nabi; dalam anggapan ini tercakup juga pendirian bahwa sastra harus berfungsi sebagai pembaharu atau perombak; (b) dari sudut lain dikatakan bahwa sastra bertugas sebagai penghibur belaka; dalam hal ini, gagasan "seni untuk seni" tak ada bedanya dengan praktik melariskan dagangan untuk mencapai best seller; (c) semacam kompromi dapat dicapai dengan meminjam sebuah slogan klasik: sastra harus mengajarkan sesuatu dengan cara menghibur (Damono, 1979:6; Faruk, 1994:5).

Karya sastra sebagai simbol ver- 
bal, menurut Kuntowijoyo (1987:127), mempunyai tiga peranan: (1) sebagai cara pemahaman (mode of comprehension), (2) cara perhubungan (mode of communication), dan (3) cara penciptaan (mode of creation). Dalam kaitannya dengan peristiwa sejarah, Kuntowijoyo lebih lanjut mendeskripsikan bahwa pada dasarnya objek karya sastra adalah realitas - apa pun juga yang dimaksud dengan realitas oleh pengarang. Bila realitas tersebut berupa peristiwa sejarah, maka karya sastra dapat dikategorikan sebagai: (1) usaha menerjemahkan peristiwa itu dalam bahasa imajiner dengan maksud untuk memahami peristiwa sejarah menurut kadar kemampuan pengarang, (2) karya sastra dapat menjadi sarana bagi pengarangnya untuk menyampaikan pikiran, perasaan, dan tanggapan mengenai suatu peristiwa sejarah, dan (3) karya sastra dapat berupa penciptaan kembali sebuah peristiwa sejarah (seperti halnya karya sejarah) sesuai dengan pengetahuan dan daya imajinasi pengarang.

Dalam karya sastra yang menjadikan peristiwa sebagai bahan, ketiga hal di atas dapat menjadi satu. Perbedaan masing-masing hanya dalam kadar campur tangan dan motivasi pengarangnya. Sebagai cara pemahaman, misalnya, kadar peristiwa sejarah sebagai aktualitas (kadar faktisitasnya) akan lebih tinggi daripada kadar imajinasi pengarang. Sebagai cara perhubungan, kedua unsur tersebut, baik faktisitasnya maupun imajinasinya memiliki kadar yang sama. Sebagai cara penciptaan, kadar aktualitas atau faktisitasnya lebih rendah daripada imajinasi pengarang. Perbedaan tersebut dalam karya sastra memang sebatas asumsi teoretis yang dalam pelaksanaannya sukar untuk dibedakan (Kuntowijoyo, 1987:127).

Novel sejarah ataupun khususnya novel sosial, menurut Kuntowijoyo (1987:134), memiliki hubungan timbal balik dengan peristiwa sejarah: (1) karya sastra menjadi saksi dan diilhami oleh zamannya, dan (2) sebaliknya karya sastra dapat mempengaruhi peristiwaperistiwa sejarah zamannya dengan membentuk sebuah public opinion. Pandangan ini mirip dengan konsep hegemoni Gramcian dalam memandang karya sastra, yang bersifat refleksif sekaligus formatif terhadap masyarakatnya (Faruk, 1994:11; Ratna, 2003:22; Nurhadi, 2004:14-30). Contoh yang pertama dapat ditemui pada banyak karya sastra. Sementara untuk karya sastra yang memenuhi kedua fungsi tersebut, misalnya, Max Havelaar (Multatuli, 1860) dan Uncle Tom's Cabin (Harriet Beecher Stowe, 1852).

Pandangan baru dalam kritik sastra yang dipengaruhi oleh new historicism membawa konsepsi yang menarik perihal sastra dan kaitannya dengan konteks sosial maupun sejarah. New historicism muncul sebagai reaksi atas new criticism yang cenderung memperlakukan karya sastra di luar konteks kesejarahannya; puisi maupun novel dalam pandangan new criticism diperlakukan sebagai sesuatu yang otonom terlepas dari konteks kesejarahannya. Sebaliknya, new historicism berlandaskan pada pernyataan bahwa: (1) citra dan karya naratif merupakan bagian penting dari karya budaya (cultural work), yang berfungsi sebagai salah satu tempat permasalahan, harapan dan obsesi budaya dialamatkan atau dihindari; (2) cara kerja terbaik dalam menginterpretasikan karya sastra yaitu dengan menempatkannya dalam konteks sejarah di mana isu-isu, kecemasan, dan pertarungan budaya kontemporer pada karya sastra tersebut direfleksikan, dibelokkan, atau diujicobakan; (3) kritik sastra hendaknya mengaitkan masalah-masalah interpretasi dengan permasalahan sejarah budaya; (4) new historicism menekankan pada pandangan bahwa pengarang atau 
penyair bukanlah orang suci, yang meskipun dalam hubungan sosialnya lebih berhati-hati daripada orang kebanyakan, mereka toh tetap berpartisipasi dalam berhubungan sosial (www.sou.edu).

Ketika sastra dan sejarah dibicarakan secara bersama-sama, segera muncul pertanyaan, apakah ada fiksi di dalam sejarah dan apakah ada fakta di dalam sastra? Secara umum, sastra selalu dikaitkan dengan fiksi, sedangkan sejarah tidak dapat dipisahkan dari fakta masa lalu. Inilah yang selama ini dipahami kalau membicarakan sastra yang bersifat fiksi. Akan tetapi, menurut Purwanto (2003:130-131), dalam wacana dekonstrukstif antara sastra dan sejarah, kategori tersebut menjadi lain. Sebagai sebuah realitas, sejarah dan sastra sering dianggap berada dalam tataran yang sama. Fiksi dan fakta tidak dapat begitu saja secara kaku diasosiasikan hanya dengan salah satu di antara keduanya, yaitu hanya berkaitan dengan sastra atau hanya dengan sejarah.

Sebagai sebuah realitas, sejarah hanya ada di masa lalu dan tidak mungkin dijangkau oleh sejarawan. Rekonstruksi sejarah adalah produk subjektif dari sebuah proses pemahaman intelektual yang dilambangkan dalam simbol-simbol kebahasaan atau naratif dan dapat berubah dari waktu ke waktu, dari satu tempat ke tempat yang lain, dari satu orang ke orang lain. Sementara itu, pada saat yang sama, sastra berhasil menampilkan citra dirinya sejajar sebagai sejarah, karena mampu menghadirkan situasi faktual dari masa lalu sebagai sebuah naratif melalui imajinasi kebahasaan. Kebenaran sejarah maupun kebenaran sastra adalah kebenaran relatif. Pada tataran praktis, antara fakta (sejarah) dan fiksi (sastra) tidak ada perbedaan yang berarti secara tekstual, sehingga sastra dan sejarah dapat diasosiasikan di dalam satu bidang yang sama, yaitu bidang bahasa
(Purwanto, 2003:130-131). Meski demikian, seperti apa yang dikemukakan Kuntowijoyo (1987:127) bahwa memang ada batas antara sastra dan fakta (sejarah) meskipun sebatas asumsi teoretis belaka. Hal ini diperkuat juga oleh Kleden dalam Jurnal Kalam edisi no 11 tahun 1998.

Salah seorang pemikir poststruktural yang melontarkan gagasan-gagasan penting bagi pengembangan kritik wacana terutama dalam kaitannya dengan kekuasaan adalah Michel Foucault. Istilah "wacana" atau diskursus mendapat arti baru, di luar pengertian yang diberikan para kritikus strukturalis. Wacana, bukan sekedar "kelompok-kelompok tanda (unsur-unsur pemaknaan yang mengacu pada isi atau representasi), melainkan cara menghasilkan pengetahuan beserta praktik-praktik yang secara sistematis membentuk objek yang dibicarakannya (Faucault, 2002:9). Melalui pengertian wacana yang baru, Foucault mengaitkan sistem pemaknaan dengan dua wilayah yang selama ini dianggap telah dilupakan oleh strukturalisme, yakni wilayah sejarah dan politik.

Dalam "The Order of Discourse", Foucault menunjukkan bahwa yang dimaksud dengan wacana tidak terbatas pada pemikiran dan cara penyampaian pemikiran tersebut, melainkan semua aturan dan kategori diskursif yang merupakan bagian dari sistem pengetahuan yang demikian mendasar sehingga tidak lagi dipertanyakan orang. Foucault menginterogasi berbagai macam kategori dan norma pengetahuan: cara menentukan apa yang boleh dipelajari dan dibahas, siapa yang boleh berbicara dan bagaimana cara memikirkan dan menyampaikan objek pembicaraan. Di sini wacana dilihat sebagai suatu sistem pengetahuan, dan sistem pengetahuan itu terkait pula dengan kekuasaan.

Wacana (termasuk di dalamnya sistem pengetahuan) dalam pembahas- 
an Foucault sangat erat kaitannya dengan konsep kekuasaan. Berbeda dengankonsepkekuasaanyangumum(yakni yang dimiliki oleh pihak-pihak yang kuat terhadap yang lemah), kekuasaan bagi Foucault (seperti diuraikan dalam Power/Konwledge, 2002a) bukanlah suatu entitas atau kapasitas yang dapat dimiliki oleh satu orang atau lembaga, melainkan dapat dapat diibaratkan dengan sebuah jaringan yang tersebar di mana-mana.

Kekuasaan tidak datang secara vertikal dari penguasa terhadap yang ditindas, dari pemerintah kepada rakyat; melainkan datang dari semua lapisan masyarakat, ke segala arah. Semua jenis hubungan dan interaksi, bagi Foucault, berkaitan dengan kekuasaan. Kekuasaan juga mengejawantah dalam bentuk-bentuk diskursif, yakni melalui wacana. Wacana (sebagai modus untuk menyampaikan atau mengaktualisasikan pengetahuan) secara langsung atau tidak langsung memproduksi kekuasaan, dan kekuasaan tak mungkin beroperasi tanpa pengetahuan.

Sebagaimana dinyatakan oleh Foucault, pengetahuan itu identik dengan kekuasaan. Kekuasaan muncul bersandarkan pada sejumlah pengetahuan; begitu juga pengetahuan melahirkan kekuasaan. Kekuasaan dan pengetahuan yang dalam buku Foucault ditulis dengan Power/Konwlegde (2002a) adalah ibarat dua sisi mata uang; satu kesatuan yang kemunculannya menuntut kehadiran sisi lainnya. Kehendak untuk tahu adalah nama lain bagi kehendak untuk berkuasa (Adian, 2002:22).

Jadi, pembahasan karya-karya sastra yang merefleksikan aspek kekerasan di Eks-Timor Timur sebagai refleksi kondisi sosial politik menggunakan kajian sosiologi sastra seperti yang telah diuraikan di depan. Penelitian ini dibatasi pada salah satu aspek tematis yaitu tentang kekerasan, suatu tema yang cukup dominan dalam realitas kehidupan di Indonesia khususnya pada masa kekuasaan pemerintah Orde Baru. Dengan langkah-langkah pembacaan semacam ini, karya-karya tersebut dapat dikaji, baik dari segi intrinsiknya maupun terhadap aspek mimetiknya dan alternatif konstruksi diskursifnya atas kondisi sosial masyarakat yang melingkupi kelahirannya. Berikut ini akan diuraikan secara ringkas perihal kekerasan, tema sentral dari penelitian ini.

Kekerasan (violence) seringkali dimaknai oleh kebanyakan orang dalam konteks yang sempit, setara dengan gambaran mengenai perang, pembunuhan, atau kerusuhan. Akan tetapi, menurut Salmi (2005:225), kekerasan dapat didefinisikan juga sebagai tindakan yang mengancam badan atau psikis orang atau sekelompok orang dan datang dari berbagai bentuk. Menurut Salmi yang merujuk pada pendapat Johann Galtung, kekerasan terbagi dalam empat jenis. Keempat jenis kekerasan tersebut yaitu: (1) kekerasan langsung (direct violence), (2) kekerasan tak langsung (indirect violence), (3) kekerasan represif (repressive violence), dan (4) kekerasan alienatif (alienating violence). Definisi kekerasan ini berkaitan dengan semua kategori kekerasan tanpa memperhitungkan berapa jumlah korbannya, siapa orangnya, dan siapa yang bertanggung jawab (apakah individu, kelompok, institusi, negara, atau masyarakat secara keseluruhan). Kebanyakan orang berbicara atau menulis tentang kekerasan biasanya hanya mengacu kepada kekerasan langsung.

Kekerasan langsung mengacu pada tindakan yang menyerang fisik atau psikologis seseorang secara langsung. Kekerasan tak langsung yaitu tindakan yang membahayakan manusia, bahkan kadang-kadang sampai membunuh, namun tidak melibatkan hubungan langsung antara korban dan 
pihak yang bertanggung jawab atas tindak kekerasan tersebut (Santoso, 2002). Kekerasan tak langsung ini dibedakan menjadi dua yaitu kekerasan karena pembiaran dan kekerasan karena dimediasi. Kekerasan jenis ketiga, yaitu kekerasan represif berkaitan dengan pencabutan hak-hak dasar selain hak untuk hidup dan hak untuk dilindungi dari kecelakaan. Ke-kerasan represif terkait dengan tiga hak dasar yaitu hak sipil, hal politik, dan hak sosial. Jenis kekerasan keempat, yakni kekerasan alienatif menyaran pada pencabutan hak-hak individu yang lebih tinggi seperti hak perkembangan emosional, budaya, atau intelektual (Salmi, 2005:226-231).

Bentuk-bentuk kekerasan yang termasuk dalam kategori kekerasan langsung yaitu semua bentuk pembunuhan (homicide) seperti pemusnahan etnis, kejahatan perang, pembunuhan massal, dan juga semua bentuk tindakan paksa dan brutal yang menyebabkan penderitaan fisik atau psikologis seseorang. Pengusiran paksa terhadap suatu masyarakat, penculikan, penyiksaan, pemerkosaan, dan penganiayaan juga termasuk jenis kekerasan langsung. Semua tindakan tersebut merupakan tindak pelanggaran HAM yang paling mendasar yakni hak untuk hidup (Sal$\mathrm{mi}, 2003: 31$ ).

Seperti telah dikemukakan di atas, kekerasan tak langsung terbagi atas dua subkategori yaitu kekerasan karena pembiaran/kelalaian (violence by omission) dan kekerasan dimediasi/perantara (mediated violence). Kekerasan karena kelalaian digambarkan dengan seseorang dalam keadaan bahaya dan tidak ada orang yang menolongnya. Kalau hendak memberikan hukuman kepada pelakunya, yakni orang yang menolak untuk menolong korban kecelakaan atau penganiayaan yang membutuhkan pertolongan segera (Salmi, 2003:32).
Bentuk kekerasan tak langsung yang kedua yaitu kekerasan dimediasi/ perantara. Berbeda dengan kekerasan karena pembiaran yang terjadi secara pasif, kekerasan dimediasi merupakan hasil dari intervensi manusia secara sengaja terhadap lingkungan alam atau sosial yang membawa pengaruh secara tidak langsung pada manusia lain. Pengaruh ini menurut Salmi (2003:3435), tidak dirasakan segera, namun datang melalui faktor perantara sehingga hubungan antara orang atau institusi yang bertanggung jawab atas tindak kekerasan ini dengan korbannya tidaklah secara langsung.

Semua bentuk ecocide atau tindak penghancuran, mengganggu, dan perusakan lingkungan alam, termasuk dalam kekerasan jenis ini, karena mengganggu kesehatan, menyebabkan manusia menderita dan sengsara. Contoh kekerasan jenis ini yaitu pemakaian agent orange, zat kimia yang banyak digunakan oleh tentara Amerika Serikat selama berlangsungnya perang Vietnam maupun oleh tentara Uni Soviet di Afganistan yang dimaksudkan untuk menghancurkan tanaman musuh yang siap dipanen. Tindakan tersebut menyebabkan malorganik genetik pada bayi-bayi yang baru lahir di daerah tersebut dan penyakit kanker pada para veteran Amerika Serikat dan Uni Soviet. Pemakaian produkproduk pestisida seperti DDT, obat Depo Provera sebagai alat kontrasepsi, pakaian bayi dari bahan carcinogenic tris fibres, maupun produk makanan yang mengandung carcinogenic cyclamate yang di negara asalnya dilarang karena dapat menyebabkan kanker atau malformasi genetik maupun keguguran, juga dapat dikategorikan tindak kekerasan tak langsung, yakni kekerasan perantara (Salmi, 2003:35).

Kebijakan agrikultur kolonial ataupun pascakolonial di berbagai negara Asia, Afrika dan Amerika Latin

Aspek Kekerasan dalam Jazz Parfum \& Insiden: Refleksi/Formatif Kondisi Sosial Politik ... 
yang mengekspor makanan hasil panennya sendiri dan justru mengkonsumsi makanan impor seringkali mengakibatkan kelangkaan persediaan makanan di kalangan masyarakat desa, juga termasuk tindak kekerasan perantara. Jika kemudian masyarakat dilanda kelaparan, maka semua itu tidaklah terjadi karena secara alamiah karena lingkungan geografis atau iklim yang buruk, atau pertumbuhan penduduk yang cepat, namun karena strategi kebijakan ekonomi yang salah.

Orang atau institusi yang bertanggung jawab atas tindak kekerasan tak langsung ini, menurut Salmi (2003:37), belum tentu dianggap pelaku kejahatan oleh hukum maupun masyarakat. Intervensi atau tindakan berbahaya yang diambilnya bisa jadi justru untuk menghargai hukum atau demi menciptakan kedamaian. Pengabaian terhadap suatu kejadian yang bisa diperkirakan juga termasuk tindak kekerasan tak langsung. Banyak korban gempa bumi pada bulan Oktober 1986 di El Savador tidak akan sampai meninggal, seandainya pascagempa tahun 1965, bangunan-bangunan yang beresiko tinggi seperti gedung pencakar langit Ruben-Dario yang telah diidentifikasi sebagai bangunan rentan gempa dihancurkan sebagaimana yang direkomendasikan oleh para ahli.

Jenis kekerasan yang ketiga yaitu kekerasan represif, yang berkaitan dengan pencabutan hak-hak dasar selain hak hidup, yakni kekerasan yang terkait dengan hak sipil, hak politik, dan hak sosial. Hak-hak sipil yang pokok adalah kebebasan berpikir dan beragama, kebebasan bergerak, privasi, kesamaan di depan hukum, dan hak untuk berusaha secara adil. Hak-hak politik mengacu pada tingkat partisipasi masyarakat secara demokratis dalam kehidupan politik di suatu daerah atau negara seperti hak untuk bersuara, mengikuti pemilihan umum, kebebasan berkumpul dan berorganisasi atau partai, kebebasan berbicara dan berpendapat, dan kebebasan pers. Hak-hak sosial perlu ditegakkan dalam rangka untuk menjamin dan melindungi kekerasan represif yang paling sering terjadi yakni larangan untuk menciptakan atau memiliki serikat buruh, atau larangan untuk mogok makan (Salmi, 2003:38).

Jenis kekerasan yang keempat yaitu kekerasan alienatif, menurut Salmi (2003:38-39), yakni pencabutan hak-hak individu yang lebih tinggi seperti hak perkembangan emosional, budaya, atau intelektual. Salah satu bentuk kekerasan alienatif yang paling kejam yaitu ethnocide, yakni kebijakan atau tindakan yang betul-betul mengubah kondisi material atau sosial menjadi di bawah satu identitas kultural kelompok tertentu. Identitas itu bisa berupa kebudayaan, seperti: (1) ketika anak-anak diajar dengan bahasa resmi selain bahasa ibu (seperti pada sebagian besar negara Afrika), (2) kurikulum pendidikan disusun secara sistematis untuk mengesampingkan latar belakang budaya siswa (seperti pada penduduk Indian di Amerika Serikat atau bangsa Kurdi di Turki, Irak dan Iran), (3) penyusunan buku-buku sejarah yang secara sengaja hanya mengkaji peristiwa-peristiwa yang dianggap penting bagi kelompok budaya tertentu (seperti pada pembasmian suku Armenia oleh bangsa Turki atau sejarah versi Jepang ketika menaklukkan Mansuria), atau (4) ketika beberapa kelompok budaya dilarang mengekspresikan identitasnya secara bebas (seperti pada orang-orang Bulgaria keturunan Turki yang dipaksa menggunakan nama-nama yang 'sepenuhnya Bulgaria').

Dalam kategori tentang jenisjenis kekerasan ini, ada peristiwa-peristiwa sejarah yang mencakup berbagai jenis kekerasan sekaligus, misalnya perdagangan budak pada abad ke-15 dan ke-19. Peristiwa tersebut dapat di- 
masukkan ke dalam empat jenis kekerasan, yakni: 1) kekerasan langsung, berupa perburuan orang untuk dijadikan budak di pesisir Afrika Barat dan perbudakan itu sendiri di Amerika Serikat; 2) kekerasan tak langsung yang berupa perlakuan terhadap budak selama dalam perjalanan menuju dan di perkebunan Amerika Serikat; 3) kekerasan represif yang berupa penegasian hak azasi manusia secara absolut dalam perbudakan; dan 4) kekerasan alienatif, berupa pencabutan budak dari desa, negara dan benuanya serta dipaksa masuk ke sebuah daerah geografis yang budaya dan sosialnya sepenuhnya mengasingkan mereka (Salmi, 2003:41-42).

Berdasarkan uraiannya tentang jenis-jenis kekerasan, Salmi (2005:232233) telah meringkaskan dimensi-dimensi pokok dari kerangka analisis kekerasan tersebut sehingga dapat dipergunakan sebagai indikasi tingkatantingkatan pertanggungjawaban pelaku tindak kekerasan.

Selain kategori di atas, Dauglas dan Waksler (Santoso, 2002:11) mendefinisikan istilah kekerasan sebagai gambaran tingkah laku, baik yang terbuka (overt) maupun yang tertutup (covert), dan baik yang bersifat menyerang (offensive) maupun bertahan (deffensive), yang disertai penggunaan kekuatan kepada orang lain. Oleh karena itu, ada empat jenis kekerasan yang dapat diidentifikasi: (1) kekerasan terbuka, kekerasan yang dapat dilihat, seperti perkelahian; (2) kekerasan tertutup, kekerasan tersembunyi atau tidak dilakukan secara langsung, seperti perilaku mengancam; (3) kekerasan agresif, kekerasan yang dilakukan tidak untuk perlindungan, tetapi untuk mendapatkan sesuatu, seperti perampasan; dan (4) kekerasan defensif, kekerasan yang dilakukan sebagai tindakan perlindungan diri. Kekerasan agresif ataupun defensif bisa bersifat terbuka atau tertutup.

\section{METODE}

Subjek penelitian ini yaitu novel Jazz, Parfum dan Insiden. Karya fiksi tersebut merupakan karya Seno Gumira Ajidarma yang diterbitkan pertama kali diterbitkan pada 1996 oleh Penerbit Bentang. Penelitian ini mempergunakan buku Jazz, Parfum dan Insiden terbitan 2004.

Penelitian ini merupakan penelitian kepustakaan. Oleh karena itu, langkah-langkah yang ditempuh berhubungan dengan pustaka atau data-data dokumentasi yang berkaitan dengan judul penelitian. Adapun langkah-langkah penelitian ini secara umum adalah sebagai berikut:

1. menetapkan subjek penelitian yaitu novel Jazz, Parfum dan Insiden karya Seno Gumira Ajidarma dan melakukan pembacaan awal guna penentuan sampel secara purposif sesuai dengan topik penelitian.

2. melakukan studi pustaka guna mencari dan mengumpulkan data-data yang berkaitan atau yang mendukung judul penelitian;

3. melakukan pembacaan dan analisis terhadap novel Jazz, Parfum dan Insiden khususnya mengenai aspek-aspek kekerasan yang terjadi di EksTimor Timur sebagai cerminan dan formasi kondisi sosial politik;

4. menarik kesimpulan dan menyusun laporan penelitian.

Instrumen atau alat pengumpul data yang dipergunakan dalam penelitian ini yaitu berupa kartu data dan kliping yang kemudian dipilah-pilah berdasarkan kelompok-kelompok atau bab pembahasan.

Sementara analisis yang dipakai yaitu berupa kajian isi atau analysis content terhadap kedua novel yang menjadi subjek penelitian dengan fokus penelitian pada aspek-aspek kekerasan yang terjadi di Eks-Timor Timur dan kajian aspek cerminan dan formasi karya sas- 
tra terhadap kondisi sosial masyarakat. Hasil penelitian disajikan dalam bentuk deskriptif kualitatif.

Untuk keabsahan data dalam penelitian ini dipergunakan teknik validitas semantis, yaitu dengan cara menganalisis konteks pemaknaan terhadap teks atau naskah. Untuk tingkat reliabilitasnya dipergunakan teknik reliabilitas intra-rater, yaitu dengan cara membaca data penelitian secara berulang-ulang sampai ditemukan kemantapan dan kepastian interpretasi.

\section{Hasil dan Pembahasan}

Temuan penelitian berupa aspekaspek kekerasan dalam novel Jazz, Parfum dan Insiden dapat dilihat dalam tabel di bawah ini. Demikian juga untuk mengetahui hasil penelitian berupa kondisi sosial politik yang menjadi latar belakang aspek kekerasan di Eks-TimorTimur dalam karya sastra ini dapat dilihat pada tabel 1 .

\section{Bentuk-bentuk Kekerasan dalam Jazz Parfum E Insiden}

Dalam roman Jazz Parfum \& Insiden, peristiwa kekerasan ditampilkan dalam subbab "Insiden" yang dimulai dari "Laporan Insiden 1" hingga "Laporan Insiden 8" yang mengacu pada peristiwa kekerasan di Timor Timur khususnya dengan Insiden Dili yang terjadi di Kuburan Santa Cruz, Dili pada November 1991 (lihat tabel 4.2). Seperti diperlihatkan pada tabel di atas, peristiwa kekerasan juga ditampilkan dalam subbab lainnya seperti pada: "Apakah Hidup Seperti Jazz?", "Seorang Wanita dengan Parfum Eternity", "Terompet Miles Davis di Malam Sunyi", "Seorang Wanita dengan Parfum Escape (untuk Pria)", Seorang Wanita dengan Parfum L'Eau d'Issey", "Wawancara dengan Bekicot", dan "Partai Kaos Oblong"

Dalam "Laporan Insiden 1" digambarkan tokoh Aku tengah membaca laporan seorang wartawati dari tiga orang narasumber, yaitu tentang penembakan massal tentara terhadap para demonstran di sebuah kuburan. Yang tewas dari pembantaian ini dilaporkan ada 19, 50 atau lebih. Dari seorang mahasiswa yang menjadi narasumber sang wartawati, tokoh Aku mengetahui bagaimana peristiwa itu terjadi. Kutipan di bawah ini sekaligus memberikan gambaran bagaimana peristiwa kekerasan langsung itu terjadi.

"Hari itu ada 3.000 orang di gereja dan sekitar 1.500 orang menunggu di kuburan, karena memang ada pengumuman dari beberapa stasiun radio: akan ada upacara tabur bunga. Jadi semua orang datang, termasuk anak kecil. Perjalanan dari gereja sampai kuburan tidak ada gangguan. Hanya, sampai di markas, katanya ada penusukan seorang tentara. Saya sendiri tidak lihat siapa yang tusuk, banyak sekali manusianya."

“... tidak lama kemudian, tiga truk tentara datang dan baru polisi berani lompat turun dari kendaraan. Di belakang kuburan, kita lihat sudah banyak dikelilingi tentara. ..."

"Tahu-tahu terdengar tembakan pertama, kita tidak tahu itu tembakan ke atas atau ke mana. Mungkin ke atas yang pertama, setelah itu langsung terdengar rentetan tembakan, selama lima menit lebih. Waktu itu saya berada di tengah. Saya lihat yang di depan berjatuhan semua. Tidak mungkin yang mati 19, karena dari satu tentara saja, selama satu detik, dengan rentetan tembakan seperti itu, sudah makan beberapa nyawa. Apalagi ini banyak tentara dan banyak massa, tidak mungkin hanya 19 orang tewas." 
Tabel 1 Peristiwa Kekerasan dalam Novel Jazz Parfum dan Insiden

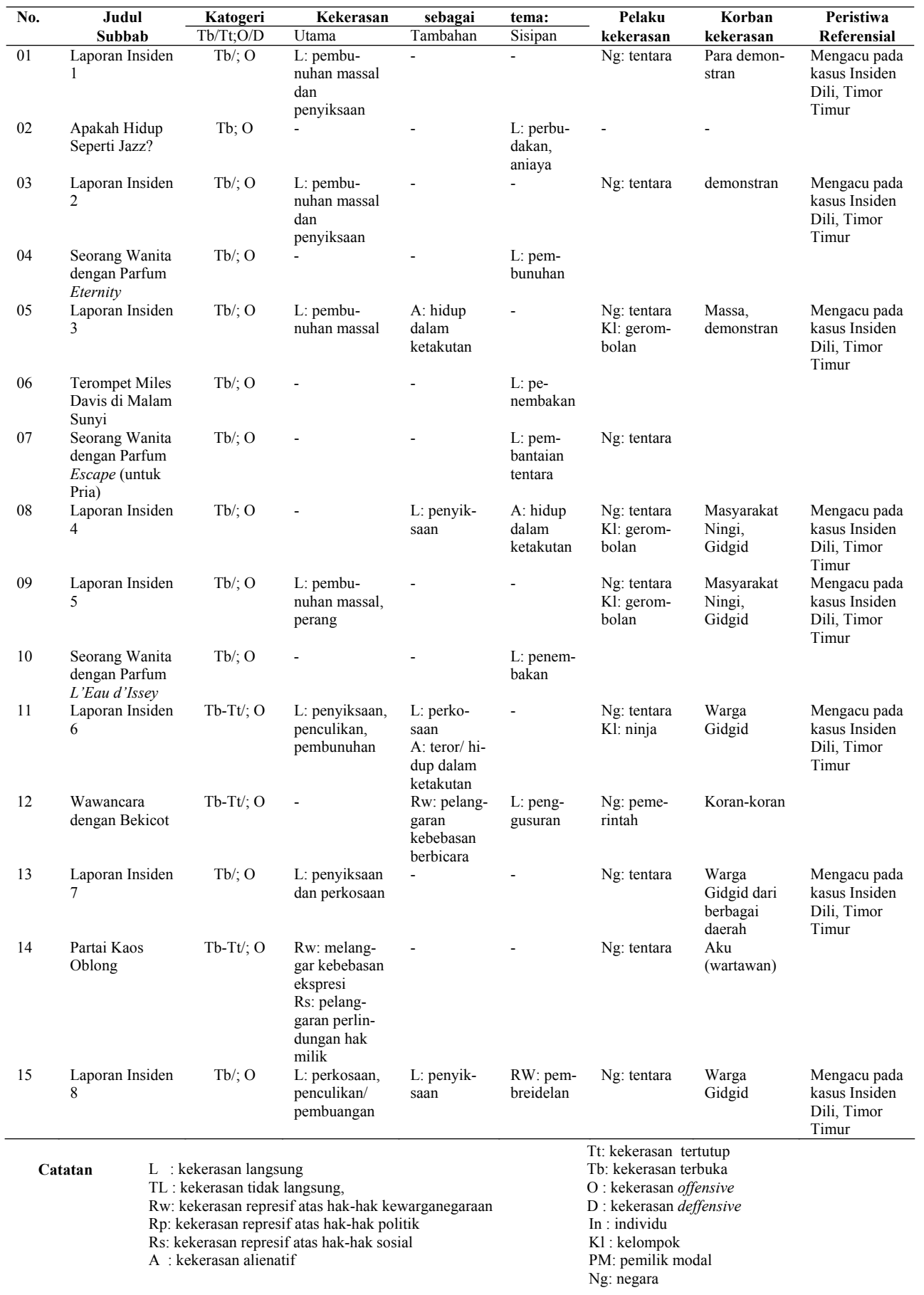




\begin{abstract}
“Banyak bukti lebih dari 19. Dari orang tua yang ditinggal anaknya, ada yang sampai lima anak yang tidak kembali. Teman-teman kita yang mati, sudah lebih dari 19. Banyak di antara teman-teman saya yang meninggal, tapi tidak tercantum dalam daftar resmi (Ajidarma, 1996:12-14).
\end{abstract}

Lewat penuturan narasumber lainnya, seorang demonstran berusia 21 tahun, diperoleh jumlah korban lebih dari 50 orang yang dalam peristiwa penembakan massal itu langsung roboh bersimbah darah. Itu pun baru dari rentetan tembakan yang pertama. Jumlah korbannya lebih dari 50 orang (Ajidarma, 1996:18). Lalu di manakah dan kapan peristiwa penembakan massal ini terjadi? Pada bagian "Laporan Insiden 1 " ini tempat dan waktu terjadinya insiden penembakan itu belum diungkap.

Pada bagian ini selain peristiwa penembakan massal, rupanya ada sejumlah adegan kekerasan langsung lainnya yakni berupa penyiksaan. Peristiwa penyiksaan rupanya telah menjadi modus di wilayah itu. Laporan dari narasumber seorang mahasiswa menguatkan adanya peristiwa kekerasan itu. "Sikap kita biasa saja waktu itu, karena kami kira seperti demonstrasi yang sudah-sudah, paling-paling kita hanya akan ditangkap, dipukuli, dan disiksa. Semua sudah percaya diri tidak akan ditembak. Jadi kami tetap berdiri di tempat dan tidak lari (Ajidarma, 1996:13)."

Peristiwa penyiksaan seperti itu juga diungkap dalam bagian lain. Berikut ini kutipan penggambaran beberapa jenis kekerasan berupa penyiksaan yang terkait dengan penembakan massal tersebut. Kutipan ini berasal dari sang narasumber seorang demonstran berusia 21 tahun.
"Setelah tembarkan antara lima sampai sepuluh menit selesai, mereka blokir sekitar kuburan supaya orang tidak bisa lari. Ketika mereka temukan yang masih hidup, termasuk saya, disuruh telanjang semua, sambil mengancam, 'Sekarang kamu semua berdoa, waktunya sudah tiba, kamu akan mati semua!' Saya waktu itu ditelanjangi, kemudian dipukuli pakai kayu, terus salah satu dari mereka mengambil bollpoint yang ada di baju saya, dan memasukkan ballpoint tersebut ke alat kelamin saya. Saya lihat teman di sebelah saya, kepalanya ditusuk pakai pisau (Ajidarma, 1996:16)."

Adegan kekerasan berupa pembunuhan massal atau penembakan massal dengan latar di sebuah kuburan juga ditampilkan pada bagian lain dari roman ini, khususnya pada subbab-subbab "Laporan Insiden" lainnya yang memang menjadi tulang punggung alur cerita roman ini. Pada bagian inilah alur kronologis tampak digambarkan memiliki hubungan kausalitas meskipun peristiwa ini ditampilkan dalam roman ini melalui sang narator, yakni tokoh Aku yang tengah membaca laporan-laporan tentang penembakan massal tersebut. Bagian-bagian lain roman ini yang bisa dikelompokkan menjadi bagian cerita lainnya yakni cerita-cerita tentang pengalaman tokoh Aku terhadap musik jazz dan pengalamannya berkenalan dengan orang-orang (khususnya perempuan) berparfum hanya semacam regresi saja, yang berupa cerita tambahan atas cerita penembakan massal tersebut (yang menjadi rangkaian cerita utama roman ini).

Roman ini hampir sepertiganya mengisahkan peristiwa kekerasan lang- 
sung terutama berupa penembakan/ pembunuhan massal sebagaimana terwakili dalam bagian "Insiden 1-8". Selain itu, sejumlah praktik kekerasan yang terkait dengan daerah pendudukan militer tampak dikemukakan dalam roman ini baik berupa penculikan, penyiksaan, perkosaan, peperangan, dan sejumlah kekerasan lainnya yang menyebabkan para penduduknya hidup dalam suasana ketakutan. Kekerasankekerasan ini dikisahkan melalui tokoh Aku yang membaca sejumlah bundel laporan terkait dengan penembakan massal terhadap pada demonstran pada bulan November 1991 di wilayah kota yang disebutnya dengan nama Ningi, di Propinsi Gidgid.

\section{Kondisi Sosial Politik yang Menjadi Latar Belakang}

Latar peristiwa faktual sosial politik apa sajakah yang menjadi acuan dalam cerpen-cerpen Seno Gumira Ajidarma yang terdapat dalam roman Jazz, Parfum $\mathcal{E}$ Insiden? Ada sebuah anagram yang bisa dijadikan kunci untuk "membaca" kaitan peristiwa historis maupun sosiologis dalam roman Jazz, Parfum $\mathcal{E}$ Insiden. Hampir semua cerita roman ini (khususnya pada bagian "Insiden") mengacu atau terkait dengan peristiwa Insiden di Santa Cruz, Dili pada 12 November 1991 atau kasus Timor Timur secara keseluruhan. Timor Timur terintegrasi dengan Indonesia pada $17 \mathrm{Juli}$ 1976, memisahkan diri sejak adanya jajak pendapat pada 30 Agustus 1999 dan kini menjadi Timor Leste.

Benarkah cerita-cerita-cerpen ini mengacu atau terkait dengan sejumlah peristiwa faktual di Timor-Timur? Hampir semua nama wilayah, kota, partai dan atribut-atribut lain yang terkait dengan bekas propinsi ke-27 Indonesia ini dinyatakan dalam sebuah anagram "bahasa walikan Jawa" yang menjadi bahasa prokem anak-anak muda di Yo- gyakarta. Sebagaimana diketahui, huruf Jawa terdiri atas 20 huruf, yaitu ha na ca ra kal da ta sa wa lall pa dha ja ya nyal ma ga ba tha nga//. Dengan mengubah cara baca ha na ca ra ka menjadi pa dha ja ya nya atau sebaliknya; dan da ta sa wa la menjadi ma ga ba tha nga atau sebaliknya; semua anagram itu akan terbaca secara kontekstual.

Kata "Ningi" sering disebut-sebut dalam Jazz, Parfum \& Insiden bersama kata "Gidgid". Jika kata-kata tersebut dibaca dengan sistem "bahasa walikan", Ningi (ni-ngi $\rightarrow$ dhi-li) menjadi Dhili (Dili) nama ibukota Timor Timur, Gidgid (gid-gid $\rightarrow$ tim-tim) menjadi Timtim singkatan dari Timor Timur. Kata "Hyegingid" (Ajidarma, 2004:42,) berasal dari Fretilin (hye-gingid $\rightarrow$ pre-ti-lin), nama partai di Timor Timur. Sejumlah nama seperti "Ngapade", "Nyongdeya”, "Ngob Hangob”, "Sapunyapu", "Pobbanguta" (Ajidarma, 2004:160-163) atau "Canyayga" (Ajidarma, 2004:189) masing-masing mengacu pada kota-kota: "Lahame (nga-pa-de $\rightarrow$ la-ha-me)", "Kolmera (nyong-de-ya $\rightarrow$ kol-me-ra)", "Los Palos (ngob-ha-ngob $\rightarrow$ los-pa-los)”, "Baucau (sa-pu-nya-pu $\rightarrow$ ba-hu-ka-hu)", "Hossaluga (pob-ba-ngu-ta $\rightarrow$ hos-sa-lu-ga)" dan "Jakarta (ca-nyay-ga $\rightarrow$ ja-kar-ta)". Dengan menguraikan kode-kode seperti ini, semua nama kota, wilayah, atau partai yang disembunyikan dalam teks fiksi ini dapat diketahui dengan lebih jelas konteks sosial politiknya.

Selain itu, dengan menganalisis sejumlah kode atau simbol yang terdapat dalam kedua karya sastra ini, TimorTimur sebagai latar dalam Jazz, Parfum $\mathcal{E}$ Insiden tidak dapat dielakkan lagi. Selain "bahasa walikan", sejumlah teknik yang disamarkan pengarang yang mengacu pada konteks Timor-Timur yaitu berupa: penamaan (naming), deskripsi lokasi geografis, hal-hal yang terkait dengan gereja katolik, peristiwa 
historis 1991 atau yang dikenal dengan Insiden Dili, dan lain-lain. Teknik penamaan (naming) merupakan penanda lain yang dapat dipergunakan untuk memperkuat bahwa latar sosial yang diangkat ke dalam kedua buku fiksi ini yaitu Timor Timur.

Teknik ketiga yang dipergunakan untuk menengarai kalau latar peristiwa dalam karya sastra ini sebagai Timor Timur yaitu berupa deskripsi lokasi geografis yang digambarkan sebagai tanah yang gersang dan tengah dilanda konflik. Dari sekian wilayah konflik yang melibatkan aparat keamanan atau tentara dengan para pemberontak kemerdekaan yang pernah terjadi di Indonesia, baik Aceh, Maluku Selatan, Timor Timur, maupun Papua, hanya Timor Timurlah yang kondisi tanahnya tidak subur alias gersang. Selain itu, latar berupa kondisi sosial budaya Kristiani khususnya Katolik makin memperkuat bahwa latar cerita-cerita ini adalah Timor Timur, bukan Papua, Maluku Selatan, apalagi Aceh (Luven, 2004).

Peristiwa pemaksaan untuk menelan rosario juga terdapat dalam Jazz Parfum $\mathcal{E}$ Insiden pada bagian "Insiden 1". Peristiwa ini merupakan bagian dari dokumen yang tengah dibaca oleh tokoh aku. "Saat di kuburan, rosario yang kami bawa dicabut salibnya, dipatahpatahkan, diinjak-injak oleh tentara dan suruh kami makan. Demikian pula dengan buku-buku doa yang kami bawa, dirobek-robek ... (Ajidarma, 1996:14)."

Hal lain yang menjadi acuan faktual dalam cerpen dan roman ini yaitu peristiwa Insiden Dili itu sendiri. Insiden Dili atau Pembantaian Santa Cruz menurut Wikipedia Indonesia (2007) adalah penembakan terhadap pemrotes Timor Timur di kuburan Santa Cruz di ibukota Dili pada 12 November 1991. Para demonstran yang kebanyakan para mahasiswa mengadakan aksi protes terhadap pemerintahan Indonesia pada penguburan rekan mereka, Sebastiao Gomes yang ditembak mati oleh pasukan Indonesia sebulan sebelumnya. Para mahasiswa telah mengantisipasi kedatangan delegasi parlemen dari Portugal, yang masih diakui PBB secara legal sebagai penguasa administrasi Timor Timur. Rencana ini dibatalkan setelah Jakarta keberatan karena hadirnya Jill Joleffe sebagai anggota delegasi itu. Joleffe adalah seorang wartawan Australia yang dipandang mendukung gerakan kemerdekaan Fretilin.

Dalam prosesi pemakaman, para mahasiswa menggelar spanduk untuk penentuan nasib sendiri dan kemerdekaan, menampilkan gambar Xanana Gusmao (pemimpin kemerdekaan). Pada saat prosesi memasuki kuburan Santa Cruz, pasukan Indonesia mulai menembak. Dari orang-orang yang berdemonstransi di kuburan itu, menurut Wikipedia Indonesia (2007) terdapat 271 tewas, 382 terluka, dan 250 hilang. Pembantaian ini tersebar ke berbagai penjuru dunia setelah rekaman video Max Stahl mengenai peristiwa ini diputar di ITV di Britania pada Januari 1992. Jumlah korban itu sendiri seringkali dilaporkan berbeda-beda. Menurut Gatra (1995) jumlah korban tewas 50 orang. Kemudian Timor Timur melepaskan diri dari Indonesia berdasarkan penentuan pendapat pada 30 Agustus 1999 dan menjadi Timor Leste.

Peristiwa Insiden Dili lebih jelas diacu dalam roman Jazz Parfum $\mathcal{E}$ Insiden khususnya pada bagian "Insiden". Dalam roman ini, juga disertakan catatan akhir berupa catatan referensial atas peristiwa-peristiwa dalam cerita. Ada sejumlah data yang diperoleh dari Amnesty International yang dalam roman ini dikutip dalam bahasa aslinya, yakni bahasa Inggris. Meski demikian, datadata refensial ini digabungkan dengan sejumlah data referensial mengenai lagu-lagu jazz dan jenis-jenis parfum 
sehingga terkesan tidak melulu tentang Insiden Dili (Ajidarma, 1996:239-252). Bahkan pada cover belakang buku Jazz Parfum E Insiden cetakan ke-4 (September 2004) dinyatakan bahwa peristiwa dalam roman tersebut "mau dianggap fiksi boleh mau dianggap fakta terserah-ini cuma sebuah roman metropolitan".

Dari data kolofon atau catatan penanggalan pada bagian akhir makin mengukuhkan kalau latar ceritanya hampir memiliki keterkaitan atau acuan dengan peristiwa Insiden Dili pada 12 November 1991. Jazz Parfum \& Insiden ditulis dengan penanggalan 1995-1996 di Taman Manggu-Palmerah. Buku ini ditulis setelah peristiwa Insiden Dili terjadi, berjarak waktu kira-kira empat tahun.

Dari paparan di atas diketahui bahwa ada sejumlah indikasi yang dapat dipergunakan untuk mengetahui peristiwa faktual yang menjadi latar cerita. Dalam kasus Jazz Parfum \& Insiden karya Seno Gumira Ajidarma peristiwa faktual yang dijadikan latar dalam cerita-ceritanya adalah peristiwa Insiden Dili 1991 ataupun peristiwa Timor Timur pada umumnya. Hal ini dapat ditelusuri berdasarkan unsur atau aspek ceritanya, catatan penanggalan, catatan publikasi dan penerbitan, serta catatan pengarang. Hal-hal semacam inilah yang makin mengukuhkan analisis bahwa kedua buku ini memiliki acuan peristiwa faktual berupa Insiden Dili pada 12 November 1991 ataupun peristiwa pendudukan Timor Timur secara keseluruhan.

\section{Peran Formatif Karya Seno Gumira Ajidarma}

Karya-karya Seno Gumira Ajidarma dalam roman Jazz Parfum \& Insiden secara tidak langsung "memberitakan" peristiwa kekerasan di wilayah Timor Timur khususnya mengenai Insiden Dili di kompleks kuburan Santa Crus pada 12 November 1991. Sebagai karya sastra yang bersifat semiotik (tepatnya sebagai second order semiotic system), kedua karya sastra ini menyampaikan sejumlah pesan atau massege secara tidak langsung. Seperti apa yang dikemukakan oleh Eagleton (2002:61-62), realitas sosial yang dicerminkan oleh karya sastra tidak dalam bentuknya yang simetris reflektif, melainkan dalam bentuknya yang dirusak (deformed), dibiaskan (refracted), ataupun dibubarkan (dissolved). Begitulah, sejumlah "fakta" mengenai Insiden Dili atau Timor Timur disampaikan secara semiotik yang dapat diungkap melalui kode-kode sastra tertentu.

Sejumlah kata walikan banyak dipakai dalam Jazz Parfum $\mathcal{E}$ Insiden. Dengan bahasa walikan ini dan sejumlah indikasi lainnya, hal-hal yang semula bersifat samar dapat diketahui sebagai tanda-tanda yang mengacu pada sejumlah peristiwa di Timor Timur. Hal tersebut diperkuat lewat pengakuan pengarangnya sendiri dalam sebuah buku yang berjudul Ketika Jurnalisme Dibungkam Sastra Harus Bicara. Buku ini dan kedua karya sastra yang menjadi objek penelitian ini merupakan sebuah trilogi mengenai Timor Timur.

Pembaca kedua fiksi Seno Gumira Ajidarma ini memang tidak secara langsung menemukan fakta tentang Insiden Dili atau kekerasan di Timor Timur. Akan tetapi, berdasarkan interpretasi dan asosiasi penafsiran terhadap kedua karya tersebut, para pembaca akan sampai pada konteks permasalahannya seperti yang telah dipaparkan pada pembahasan mengenai konteks latar belakang kondisi sosial di depan. Lewat kedua karya ini, pembaca disuguhi "fakta" tentang sejumlah kekerasan yang jelas-jelas melanggar hak asasi manusia di wilayah eks-Timur Timur.

Cerpen dan roman, dalam kasus ini, telah dijadikan sarana untuk me- 
nyampaikan suatu pesan ketika jurnalisme mengalami sejumlah pembredelan atau self cencorship seperti apa yang dikemukakan Seno Gumira Ajidarma dalam buku Ketika Jurnalisme Dibungkam Sastra Harus Bicara (1997:48--91). Hal ini juga diungkapkan kembali dalam catatan akhir roman Jazz Parfum \& Insiden (Ajidarma, 2004:251-252). Hal yang serupa juga terdapat pada catatan penulis dalam antologi Saksi Mata (Ajidarma, 2002:vii-ix).

Dalam perspektif Belsey, apa yang dilakukan Seno Gumira Ajidarma khususnya lewat karya ini merupakan salah satu tindak interogatif atas suatu wacana. Berdasarkan fungsi wacananya, sebuah teks menurut Belsey setidaknya mewakili tiga kemungkinan: sebagai teks deklaratif, imperatif, atau interogatif (Allen, 2004:13--15). Teks deklaratif adalah realisme klasik yang membuat posisi pembaca menjadi stabil. Teks realis bertujuan memantapkan suatu posisi spekularitas dominan bagi pembaca "sebagai orang yang memandang dari luar. Contoh teks deklaratif dalam penelitian Allen (2004:13-14) adalah tetralogi Bumi Manusia karya Pramoedya Ananta Toer dan Burung-Burung Manyar serta Burung-Burung Rantau karya Mangunwijaya.

Teks imperatif memberi perintah kepada pembaca untuk menerima satu posisi perjuangan melawan sesuatu yang nonfiksional dalam teks tersebut. Belsey memberikan contoh sesuatu yang nonfiksional ini misalnya: "dosa", "Partai Konservatif", dan "Rusia". Teks tersebut mengundang atau "mendesak" pembaca untuk ikut dalam suatu perjuangan melawan entitas ekstra-tekstual yang nonfiksional. Jenis teks imperatif yang ekstrim bernada propaganda. Menurut Allen (2004:14), tetralogi Bumi Manusia karya Pramoedya Ananta Toer bisa juga dianggap sebagai serangkaian teks imperatif dengan tempat-tempat pergulatan yang nonfiksional seperti struktur kekuasaan feodalistik, konflik kelas dan/atau kolonialisme.

Teks interogatif membuat pembaca gelisah; teks semacam ini tidak memberi informasi, tetapi justru mengundang pembaca untuk memberikan jawaban atas pertanyaan-pertanyaan yang muncul dalam teks itu. Narasinya tidak menggiring ke arah penutupan teks realis klasik. Novel modernis dan pascamodernis adalah contoh dari wacana interogatif; teks semacam itu meletakkan "rasa aman pembaca dalam kesangsian". Teks-teks yang dapat digolongkan dalam kategori teks interogatif dalam penelitian Allen adalah Durga Umayi karya Mangunwijaya dan karyakarya Putu Wijaya seperti: Teror, Sobat, Kroco, Byar Pet, dan Perang. Dengan klasifikasi teks-teks tersebut, intensi pengarang dapat diduga (Allen, 2004:15).

Dalam kasus karya Seno Gumira Ajidarma ini, penyampaian "fakta" kekerasan di Timor Timur bukanlah tujuan utamanya, melainkan usaha mempertanyakan sejumlah tindak kekerasan yang dilakukan oleh aparat negara di wilayah itu. Negara tidak memiliki legitimasi apa pun untuk melakukan tindak kekerasan di wilayah itu. Apa landasan legitimasi negara untuk melakukan pembunuhan massal (massacre) seperti roman Jazz Parfum E Insiden? Apa landasan legitimasi negara untuk melakukan tindak pembunuhan, penyiksaan, pemerkosaan, penculikan, pelarangan, dan sejumlah kekerasan lainnya (seperti dalam tabel 1)? Inilah yang menjadi massage dari buku Seno Gumira Ajidarma ini.

Seno Gumira Ajidarma sendiri dalam "Catatan Penulis" buku Saksi Mata cetakan ke-4 (2002), sekitar sepuluh tahun dari rentang Insiden Dili, mempertanyakan landasan legitimasi atas tindak kekerasan yang menghilangkan nyawa ratusan jiwa itu. 
Dalam kategori Kuntowijoyo (1987:127--134), kedua fiksi Seno Gumira Ajidarma ini telah memenuhi peranannya sebagai cara perhubungan (mode of communication). Seno Gumira Ajidarma lewat kedua karyanya ini telah menyampaikan pikiran, perasaan, dan tanggapan mengenai suatu peristiwa sejarah, dalam konteks ini yaitu Insiden Dili 1991 atau kekerasan di Timor Timur secara umum. Seno Gumira Ajidarma tidak berusaha mengajak pembacanya untuk memahami peristiwa Insiden Dili, yakni sebagai cara pemahaman (mode of comprehension) ataupun sebagai sarana untuk sekedar menciptakan kembali sejarah peristiwa Insiden Dili atau Timor Timur, yakni sebagai cara penciptaan (mode of creation). Lewat roman Jazz Parfum $\mathcal{E}$ Insiden, Seno Gumira Ajidarma telah mempertanyakan tindak kekerasan aparat negara terhadap orang-orang yang telah menjadi korban dalam Insiden Dili dan pendudukan Timor Timur.

Dalam pandangan Foucault mengenai diskursus, apa yang ditulis Seno Gumira Ajidarma, khususnya dalam karya fiksinya ini turut memperkuat sebuah kategori atas pemerintahan Orde Baru yang bersifat otoriter. Lewat aparat negaranya seperti digambarkan dalam roman Jazz Parfum \& Insiden, diskursus mengenai pemerintahan Orde Baru khususnya dalam pendudukannya atas wilayah Timor Timur semakin merosot. Karya-karya semacam roman Jazz Parfum $\mathcal{E}$ Insiden turut memperlemah posisi Orde Baru. Citra Orde Baru sebagai pemerintahan yang otoriter militeristik semakin menguat yang mengakibatkan runtuhnya orde ini pada 1998. Tentu saja juga akibat berbagai aspek lainnya yang turut menjatuhkan pemerintahan Soeharto, khususnya dari segi ekonomi.

Selain dibaca di dalam negeri, karya-karya Seno Gumira Ajidarma juga dibaca dan diapresiasi oleh pembaca yang berbahasa asing di luar negeri. Hal yang serupa juga terjadi pada roman Jazz Parfum $\mathcal{E}$ Insiden yang diterjemahkan ke dalam bahasa Inggris oleh Gregory Harris dan diterbitkan oleh The Lontar Foundation, Jakarta pada 2002. Kedua karya fiksi Seno Gumira Ajidarma ini memiliki cakupan pembaca yang luas, tidak hanya di Indonesia tetapi juga di luar negeri.

Seno Gumira Ajidarma sendiri dalam konstelasi pengarang Indonesia merupakan pengarang hegemonik, artinya dia termasuk pengarang yang sejalan dengan ideologi pemerintahan Orde Baru yang bersifat kapitalistik, tetapi sebagai aparatus hegemoni, Seno Gumira Ajidarma juga melakukan otokritik. Dalam konteks kedua karya yang menjadi objek penelitian ini, Seno melakukan kritik atas pemerintahan Orde Baru yang bersifat otoriter militeristik dengan sejumlah catatan pelanggaran hak asasi manusia, khususnya dalam melakukan tindak kekerasan, termasuk di wilayah yang kini disebut Timor Leste atau eksTimor Timur.

Karya-karya Seno Gumira Ajidarma, khususnya Jazz Parfum \& Insiden turut memberi andil dalam kemerdekaan Timor Timur pada 1999. Jazz Parfum $\mathcal{E}$ Insiden telah melakukan peran formatif terhadap kesadaran pembaca akan sejumlah pelanggaran hak asasi manusia dalam kasus Insiden Dili 1991 atau kasus pendudukan Timor Timur pada umumnya oleh aparat negara pemerintahan Orde Baru. Sebuah sekuel tindak kekerasan yang terentang dari awal berdirinya Orde Baru pada 1968 (yang ditandai pembantaian orang-orang PKI) hingga berakhirnya orde ini pada 1998 (yang ditandai dengan Peristiwa Mei 1998).

\section{Simpulan}

Berdasarkan uraian pembahasan di atas, dapat disimpulkan sejumlah hal sebagai berikut: (1) aspek-aspek 
kekerasan yang terdapat dalam novel Jazz, Parfum dan Insiden antara lain itu pembunuhan, penyiksaan, penculikan, pemerkosaan dan sejumlah kekerasan lain yang terjadi akibat peperangan atau daerah konflik; (2) kondisi sosial politik yang menjadi latar belakang aspek kekerasan berupa berupa pelanggaran hak asasi manusia dari roman Jazz Parfum $\mathcal{E}$ Isiden yaitu Insdien Dili 12 November 1991 di kuburan Santa Cruz dan kondisi pendudukan Timor Timur secara umum; (3) karya fiksi Seno Gumira Ajidarma tersebut telah berperan secara formatif terhadap kesadaran pembaca akan sejumlah tindak kekerasan aparat negara atas pendudukan Timor Timur oleh pemerintahan Orde Baru yang cenderung otoriter militeristik sehingga kedua karya ini secara tidak langsung turut memberikan andil atas kejatuhan pemerintahan Orde Baru dan kemerdekaan Timor Leste.

Berdasarkan pembahasan dan kesimpulan di atas, penelitian ini mempunyai sejumlah implikasi sebagai berikut. Pertama, secara teoretis, penelitian diharapkan dapat menyumbangkan satu poin yaitu mengenai suatu temuan salah satu bentuk penerapan kajian aspek kekerasan yang terdapat dalam karya-karya sastra Indonesia yang berlatarkan eks-Timor Timur sebagai bentuk refleksi kondisi sosial politik bagi pembahasan kritik sastra Indonesia. Kedua, secara praktis, hasil penelitian mengenai aspek kekerasan dalam karya-karya Seno Gumira Ajidarma ini diharapkan dapat membantu masyarakat dalam mengkritisi aspek-aspek kekerasan yang telah terjadi di Eks-Timor Timur secara lebih bijak. Dengan demikian, dalam menyikapi permasalahan pelanggaran HAM di Eks-Timor Timur dapat dilihat dari berbagai sudut padang dan berbagai kriteria sehingga tidak cenderung menjustifikasi berdasarkan keyakinannya semata-mata. Lewat kacamata kar- ya sastra dan kemungkinan kekuatan formasinya, permasalahan pelanggaran HAM tersebut dapat dilihat secara lebih utuh.

\section{UCAPAN TERIMA KASIH}

Artikel ini diangkat dari penelitian mandiri swadana yang dilaksanakan pada tahun 2007. Ucapan terima kasih disampaikan kepada para mahasiswa yang telah membantu pelakasanan pengumpulan data dan kepada mitra sejawat yang telah membantu kegiatan verifikasi dan triangulasi data dan hasil penelitian.

\section{DAFTAR PUSTAKA}

Adian, Donny Gahral. 2002. "Berfilsafat Tanpa Sabuk Pengaman, Sebuah Pengantar," dalam Pengetahuan dan Metode, Karya-Karya Penting Foucault. Yogyakarta: Jalasutra.

Ajidarma, Seno Gumira. 1997. Ketika Jurnalisme Dibungkam Sastra Harus Bicara. Yogyakarta: Bentang Budaya.

Ajidarma, Seno Gumira. 2004. Jazz, Parfum, dan Insiden. Yogyakarta: Yayasan Bentang Budaya.

Ajidarma, Seno Gumira. 1994. Saksi Mata. Yogyakarta: Yayasan Bentang Budaya.

Allen, Pamela. 2004. Membaca, dan Membaca Lagi; [Re]interpretasi Fiksi Indonesia 1980-1995 (penerjemah Bakdi Soemanto). Magelang: Indonesiatera.

Anonim. 2006. "Susilo-Xanana Akan Bertemu Satu-Dua Minggu Mendatang," Kompas. Edisi 28 Januari.

Bodden, Michael H. 2002. "Seno Gumira Ajidarma and Fictional Resistence to An Autoritarian State in 1990s Indonesia," dalam Indonesia edisi Oktober 1999.

Damono, Sapardi Djoko. 1979. Sosiologi Sastra Sebuah Pengantar Ringkas. 
Jakarta: Pusat Pembinaan dan Pengembangan Bahasa Depdikbud.

Donna, Angelina Maria. 2006. "Menhan: Isu Napalm, Isu Lama," Kompas. Edisi 20 Januari.

Eagleton, Terry. 2002. Marxisme dan Kritik Sastra. Terj. Roza Muliati dkk. Yogyakarta: Sumbu.

Faruk. 1994. Pengantar Sosiologi Sastra. Yogyakarta: Pustaka Pelajar.

Foucault, Michel. 2002. Pengetahuan dan Metode, Karya-Karya Penting Foucault. Yogyakarta: Jalasutra.

"Insiden Dili," http://id.wikipedia.org/ wiki/insiden_dili. Diakses pada 2 Agustus 2007.

Kuntowijoyo. 1987. Budaya dan Masyarakat. Yogyakarta: Tiara Wacana Yogya.

Luven, Lynne van. 2004. "An Indonesian Journalist Uses the Genre of Fiction to Convey Real-Life Information About Atrocities and Oppression," www.caj.ca/mediamag/ sppring99-3.htm. Diakses 13 Mei 2004.
Purwanto, Bambang. 2003. "Historisisme Baru dan Penulisan Sejarah," dalam Muh. Arif Rokhman dkk., Sastra Interdisipliner. Yogyakarta: Qalam.

Ratna, Nyoman Kutha. 2003. Paradigma Sosiologi Sastra. Yogyakarta: Pustaka Pelajar.

Salmi, Jamil. 2005. Violence and Democratic Society. Yogyakarta: Pilar Media.

Salmi, Jamil. 2003. Kekerasan dan Kapitalisme. Yogyakarta: Pustaka Pelajar.

Santoso, Thomas. 2002. Teori-teori Kekerasan. Jakarta: Ghalia Indonesia.

Wellek, Rene dan Austin Warren. 1990 (cet. II). Teori Kesusastraan. Terjemahan Melani Budianta. Jakarta: PT Gramedia. 